Meta

Journal des tradlucteurs

Translators' Journal

\title{
Dictionnaire Contextuel anglais-français de la chromatographie
}

\section{Robert Serré}

Volume 26, numéro 3, septembre 1981

URI : https://id.erudit.org/iderudit/004112ar

DOI : https://doi.org/10.7202/004112ar

Aller au sommaire du numéro

Éditeur(s)

Les Presses de l'Université de Montréal

ISSN

0026-0452 (imprimé)

1492-1421 (numérique)

Découvrir la revue

Citer cet article

Serré, R. (1981). Dictionnaire Contextuel anglais-français de la

chromatographie. Meta, 26(3), 281-284. https://doi.org/10.7202/004112ar d'utilisation que vous pouvez consulter en ligne.

https://apropos.erudit.org/fr/usagers/politique-dutilisation/ 


\section{DICTIONNAIRE CONTEXTUEL ANGLAIS-FRANÇAIS DE LA CHROMATOGRAPHIE}

La chromatographie est un puissant instrument d'analyse chimique dont les origines remontent au début de notre siècle, mais dont le véritable essor est survenu depuis la Seconde Guerre mondiale, les années soixante étant surtout marquées par la chromatographie en phase gazeuse et les années soixante-dix par la chromatographie en phase liquide.

Il existe aujourd'hui de nombreuses formes de chromatographie, mais toutes servent essentiellement à séparer les constituants d'un mélange grâce à la migration différentielle de ceux-ci dans un substrat quelconque.

La chromatographie est utilisée non seulement en laboratoire mais aussi en. usine, où elle sert à l'analyse automatique dans diverses chaînes de production, et elle a trouvé des applications dans de nombreux domaines scientifiques et techniques : secteur alimentaire, analyse des métaux, pétrochimie, parfumerie, chimie pharmaceutique, pollution, toxicologie, etc.

Le Dictionnaire contextuel anglais-français de la chromatographie, publié en juillet 1981*, devrait donc rendre service. Compilé en fonction des besoins bien précis du traducteur, ce dictionnaire englobe 375 entrées principales, dont chacune fournit une définition en anglais, avec source, et un ou plusieurs équivalents français, en contexte, également avec source. Ces entrées, accompagnées de nombreux renvois, sont suivies de 110 abréviations et sigles, de 91 références bibliographiques et d'un index français-anglais.

À titre d'exemple, quinze des entrées les plus intéressantes sont reproduites ici, suivies d'une liste des sources citées.

\section{B-1 BACKFLUSH}

Aussi : backflushing, carrier gas inversion

The reversal of direction of flow through the column, after some components have been eluted, to remove those of long retention time (BSI 1969 8)

- la technique classique du rétrobalayage en chromatographie industrielle qui permet l'élimination du solvant de giclage (Bèche 1980 33)

- il est donc nécessaire de réaliser un contre-balayage (Prévot 1980 498)

B-15 BYPASS INJECTOR

Aussi : by-pass injector, loop injector, valve injector

Voir aussi : sample loop

A sample injector by means of which the eluent (carrier gas) may be temporarily diverted through a sample chamber so that the sample is carried to the column (Irving 1978 79)

- pompe équipée d'un injecteur à boucle (Mahuzier 1979 362)

\section{C-7 CARRIER GAS}

Aussi : eluent gas

Voir aussi : mean carrier gas velocity

Carrier gas (or eluent gas) is gas used to elute the sample as it passes through the column; the carrier gas together with the portions of the sample present in this phase constitutes the mobile phase (Irving 1978 65)

*Adresse de l'auteur: Robert Serré, 1057 Riviera Drive, Ottawa, Canada, K1K 0N7. 
- les détecteurs décèlent la présence des substances dans le gaz vecteur (Mahuzier 1978 202)

- pendant tout le temps que dure l'analyse, le gaz porteur alimente la colonne du chromatographe (Bèche 1980 32)

\section{E-5 EFFLUENT SPLITTER}

Division of the effluent from the column to give two or more separate streams is achieved by means of effluent splitters (Denney 1976 54)

- utilisation d'un diviseur d'effluent à l'entrée du spectromètre de masse (Rosset 197827 )

\section{E-22 EXCLUSION LIMIT}

In gel permeation chromatography, the molecular weight above which molecules are incapable of penetrating the gel pores and are eluted with the void volume of the column (Denney 1976 62)

- les molécules de masses (ou de dimensions) supérieures à la limite de porosité du gel (fraction exclue) (Faure 1975 440)

\section{F-7 FLAT-BED CHROMATOGRAPHY}

Aussi : planar chromatography, plane chromatography

Common term for thin layer or paper chromatography occurring in a single plane (Touchstone 1978 xviii)

- la chromatographie de surface qui n'exige qu'un matériel simple (Munier 1975 162)

\section{F-19 FRONTING}

Voir aussi : tailing

Asymmetry of a peak such that, relative to the baseline, the front is less steep than the rear (Irving 1978 77)

- la traînée ou la diffusion frontale des pics sont évidemment néfastes à une bonne séparation des pics voisins (Tranchant 1968 16)

\section{I-3 INJECTION PORT}

Aussi : injection block, inlet system

Closure column on one side and a septum inlet on the other through which the sample is introduced into system (Grob 1977 26)

- (la colonne) est précédée d'une chambre d'injection à température plus élevée (Berthillier 1972 89)

- la température de la chambre d'introduction (Tranchant 1968 11)

\section{L-5 LINEAR DYNAMIC RANGE}

The portion of the dynamic range over which the input/output ratio remains sensibly constant (BSI 1969 8)

- un domaine de linéarité du détecteur plus étroit (Albaigés 1976 444)

\section{R-3 RATE THEORY}

Voir aussi : plate theory

Rate theory is based on such parameters as rate of mass transfer between stationary and mobile phases, diffusion rate of solute along the column, carrier gas flowrate, and the hydrodynamics of the mobile phase (Grob 1977 65)

- la théorie cinétique qui est basée sur les phénomènes d'écoulement des fluides (Vernin 1970 12)

\section{S-6 SECOND VIRIAL COEFFICIENT}

The second virial coefficient gives the correction to the ideal gas equation of state due to two-body clustering (Reichl 1980 362)

- la valeur du second coefficient du viriel du soluté pur est souvent difficile à trouver (Guiochon 1971 296) 


\section{S-26 SOLVENT REGAIN}

The amount of solvent taken up by $1 \mathrm{~g}$ of dry xerogel in swelling to an equilibrium state in that solvent (Denney 1976 149-150)

- la capacité de gonflement d'un gel sert souvent à caractériser sa porosité : c'est la quantité de solvant capable d'être absorbée par gramme de gel sec (Mahuzier 1978 162)

\section{T-1 TAILING}

Voir aussi : fronting

Asymmetry of a peak such that, relative to the base line, the front is steeper than the rear (Irving 1978 77)

- une déformation du pic chromatographique sous forme de traînée (Ferraris 1979 335)

\section{V-3 VAPOR-PHASE CHROMATOGRAPHY}

Aussi : vapour phase chromatography

This term is no longer employed generally for what is now called gas chromatography (Denney 1976 170)

- la chromatographie en phase vapeur (C.P.V.) (Faugère 1979 227)

\section{W-3 WATER REGAIN}

The water regain represents the amount of water (in $\mathrm{ml}$ ), imbibed by one gram of dry xerogel, on swelling (Fischer 1980 23)

- l'indice de rétention d'eau, qui est la quantité d'eau absorbée pour $1 \mathrm{~g}$ de gel sec (Berthillier 1972 140)

ROBERT SERRÉ

\section{BIBLIOGRAPHIE}

ALBAIGÉS J. et al. (1976): «Évaluation des méthodes chimiques, spectroscopiques et chromatographiques utilisables pour l'identification des polluants pétroliers en mer", $R e$ vue de l'Institut français du pétrole $31: 3$, p. 427-450.

BËCHE, M. et al. (1980): "Injection pulsée de produits liquides en chromatographie en phase gazeuse automatique industrielle ", Analusis 8: 1, p. 31-34.

BERTHILLIER, Alain (1972): la Chromatographie et ses applications, Paris, Dunod, xvii$199 \mathrm{p}$.

BRITISH STANDARDS INSTITUTION (1969): Glossary of terms relating to gas chromatography (BS 3282), London, BSI, $18 \mathrm{p}$.

DENNEY, Ronald C. (1976): A dictionary of chromatography, New York, John Wiley \& Sons, $\mathrm{xi}-191 \mathrm{p}$

FAUGËRE, J.-G. (1979): «Applications de la chromatographie liquide haute-performance à l'analyse des conservateurs en alimentation humaine", Annales des falsifications et de l'expertise chimique $72: 774$, p. 227-231.

FAURE, J. et al. (1975) : "La chromatographie sur gel et l'ultrafiltration appliquées au fractionnement des substances organiques des sédiments et des eaux du Rhône », la Tribune du CEBEDEAU $28: 385$, p. $439-450$.

FERRARIS, G. et M. LAURET (1979): «Nouveaux dispositifs d'injection pour la chromatographie en phase liquide analytique et préparative $»$, Analusis 7: 7-8, p. 334-338.

FISCHER, L. (1980): Gel filtration chromatography, Amsterdam, Elsevier/North-Holland Biomedical Press, 2nd fully revised edition, viii-269 p.

GROB, Robert L., ed. (1977) : Modern practice of gas chromatography, New York, John Wiley \& Sons, xvi-654 p.

GUIOCHON, G. et C. POMMIER (1971) : la Chromatographie en phase gazeuse en chimie inorganique, Paris, Gauthier-Villars, xxiv-355 p.

IRVING, H.M.N.H. et al. (1978): Compendium of analytical nomenclature, Definitive rules 1977 (IUPAC), Oxford, Pergamon Press, viii-223 p. 
MAHUZIER, G. et M. HAMON (1978): Abrégé de chimie analytique à l'usage des étudiants en pharmacie, Tome 2: Méthodes de séparation, Paris, Masson, x-244 p.

MAHUZIER, G. et al. (1979): «Application de la chromatographie en phase liquide à la détermination simultanée des anticonvulsivants dans le plasma», Analysis $7: 7-8$, p. 360365 .

MUNIER, Roger L. (1975): «Aspects récents de la chromatographie en phase liquide des aminoacides et des peptides", Actualités de chimie analytique 23, p. 161-228.

PREVOT, A. et al. (1980): "Recherche de capteurs physicochimiques pour la mesure de 1'acidité des huiles ", Revue française des corps gras $27 ; 11$, p. 493-503.

REICHL, L.E. (1980): A modern course in statistical physics, Austin, University of Texas Press, xii-709 p.

ROSSET, Robert et Marcel CAUDE (1978): «La chromatographie en phase liquide moderne et ses applications ", I'Actualité chimique 2, p. 22-34.

TOUCHSTONE, Joseph C. et Murrell F. DOBBINS (1978): Practice of thin layer chromatography, New York, John Wiley \& Sons, xxiii-383 p.

TRANCHANT, Jean et al. (1968): Manuel pratique de chromatographie en phase gazeuse, Paris, Masson, $2^{\mathrm{e}}$ éd., xi-361 p.

VERNIN, Gaston (1970): la Chromatographie en couche mince, Techniques et applications en chimie organique, Paris, Dunod, xi-178 p. 